\title{
EFFECTS OF MINIMAL-DOSE APROTININ ON CORONARY ARTERY BYPASS GRAFTING
}

Nobuhiko Hayashida, MD

Tadashi Isomura, MD

Tohru Sato, MD

Hiroshi Maruyama, MD

Kenichi Kosuga, MD

Shigeaki Aoyagi, MD
Objective: To evaluate the effects of minimal-dose aprotinin in patients undergoing coronary artery bypass grafting, we conducted a prospective randomized study. Methods: A total of 167 patients were randomized to receive no aprotinin treatment (control, $n=57$ ), minimal-dose aprotinin $\left(1.0 \times 10^{6} \mathrm{KIU} ; n=55\right)$, or low-dose aprotinin $\left(2.7 \pm 0.5 \times 10^{6} \mathrm{KIU} ; n=\right.$ 55). Blood loss and transfusion requirements, parameters of clotting and fibrinolysis, renal function, and early graft patency rates were assessed. Results: Postoperative blood loss and transfusion requirements were significantly $(p=0.01$ ) lower in both the minimal-dose and low-dose groups than in the control group. The increase in D-dimer level after cardiopulmonary bypass was significantly $(p<0.05$ ) less marked in the low-dose group than in the control group. The $\alpha_{2}$-plasmin inhibitor and plasminogen activator inhibitor-1 levels were significantly $(p<0.05)$ greater in the minimal-dose and low-dose groups than in the control group after bypass, suggesting the prevention of fibrinolysis by both aprotinin doses. No statistically significant differences in postoperative renal function and early vein graft patency rates were noted (control group, 93.8\%; minimal-dose group, 98.5\%; low-dose group, 92.3\%; $p=0.25$ ). Conclusions: Aprotinin was not associated with a significant increase in the prevalence of renal dysfunction or early vein graft occlusion. Minimal-dose aprotinin inhibited enhanced fibrinolytic activity and reduced blood loss and transfusion requirements after bypass equivalently to low-dose aprotinin. The dose of $1 \times 10^{6} \mathrm{KIU}$ added to the pump prime may be acceptably effective in reducing blood loss in patients undergoing primary coronary operations. (J Thorac Cardiovasc Surg 1997;114:261-9)
$A_{\mathrm{e}}^{\mathrm{p}}$ protinin has been reported to decrease postoperative blood loss and transfusion requirements in patients undergoing cardiac operations. ${ }^{1-4}$ The mechanisms of action of aprotinin in reducing blood loss are still controversial, although the drug has been shown to preserve platelet membrane receptor glycoprotein $\mathrm{Ib},{ }^{5}$ to inhibit the intrinsic clotting system, ${ }^{6}$ and to prevent fibrinolysis. ${ }^{3-5,7,8}$ Although aprotinin markedly improved hemostasis, concerns about the side

From the Second Department of Surgery, Kurume University Hospital, Kurume, Fukuoka, Japan.

Presented at the Sixty-ninth Scientific Sessions of the American Heart Association, New Orleans, La., Nov. 13, 1996.

Received for publication Oct. 21, 1996; revisions requested Nov. 26, 1996; revisions received Jan. 11, 1997; accepted for publication Feb. 21, 1997

Address for reprints: Nobuhiko Hayashida, MD, The Second Department of Surgery, Kurume University Hospital, 67 Asahi-machi, Kurume, Fukuoka, 830 Japan.

Copyright (C) 1997 by Mosby-Year Book, Inc.

$0022-5223 / 97 \$ 5.00+0 \quad \mathbf{1 2 / 1 / 8 1 3 9 5}$ effects of high-dose aprotinin such as early vein graft thrombosis and renal dysfunction have been raised. ${ }^{9-11}$ The possibility exists, therefore, that any reduced dose with hemostatic efficacy comparable with that of highdose aprotinin could reduce the prevalence of the adverse side effects. Recently, half of the standard high dose of aprotinin reported by Royston and associates ${ }^{1}$ was reported to be effective. ${ }^{7,8}$ However, an acceptable minimal-dose regimen that would provide the best risk/benefit balance has not yet been suggested.

The purpose of this study was to evaluate the effects of minimal-dose $\left(1 \times 10^{6} \mathrm{KIU}\right)$ aprotinin on blood loss and transfusion requirements, clotting and fibrinolysis, renal function, and early graft patency in patients undergoing coronary artery bypass grafting (CABG).

\section{Methods}

Patient population, aprotinin administration, and surgical techniques. A prospective randomized study was performed on 167 patients undergoing primary isolated 
CABG by one surgeon (T.I.). Seventy-eight patients were receiving aspirin or a nonsteroidal antiinflammatory drug before the operation. Administration of these plateletactive drugs was discontinued at least 10 days before the operation in all patients. The patients were randomized into three groups according to the dose of aprotinin (1.4 mg of aprotinin, or 10,000 kallikrein inactivator units per milliliter; Bayer Yakuhin Ltd., Osaka, Japan) by means of a computer-generated randomization table. The control group received no aprotinin treatment $(n=57)$; the minimal-dose group received $1 \times 10^{6} \mathrm{KIU}$ aprotinin only in the cardiopulmonary bypass (CPB) priming solution $(n=55)$; and the low-dose group received $3 \times 10^{4} \mathrm{KIU} / \mathrm{kg}$ aprotinin in the priming solution and continuous infusion of aprotinin at a rate of $0.75 \times 10^{4} \mathrm{KIU} / \mathrm{kg}$ every hour during $\mathrm{CPB}^{7}(n=55)$. The mean dose of aprotinin in the low-dose group was $2.7 \pm 0.1 \times 10^{6} \mathrm{KIU}$ (range $1.4 \times 10^{6}$ to $\left.4.0 \times 10^{6} \mathrm{KIU}\right)$. So that the investigators would remain blinded to the protocol, only the perfusionists were informed regarding the administration of the regimen; surgeons and others participating in patient care were not. Before CPB was initiated, heparin sodium was administered at an initial dose of $300 \mathrm{IU} / \mathrm{kg}$. Additional heparin was administered if the celite-activated clotting time (Hemochron 401, International Technidyne Corporation, Edison, N.J.) became less than 400 seconds. CPB was constructed with single two-staged right atrial cannulation and ascending aortic cannulation. The systemic temperature was allowed to drift to $33^{\circ} \pm 1^{\circ} \mathrm{C}$ and perfusion flow during $\mathrm{CPB}$ was maintained at 2.5 to $2.6 \mathrm{~L} / \mathrm{min}$. Blood cardioplegic solution at $30^{\circ} \pm 1^{\circ} \mathrm{C}$ was delivered through the aortic root and completed vein grafts in an intermittent antegrade fashion. All patients signed a consent form approved by the Human Experimental Committee of Kurume University Hospital.

Postoperative blood loss and transfusion requirements. Before closure of the sternotomy, chest tubes were inserted and the volume of blood loss drained from the tubes was measured 3, 6, 12, and 24 hours after CPB. The use of homologous blood products was carefully controlled according to the hemoglobin level, which was measured at regular intervals. Red blood cells or whole blood was administered only if the hemoglobin level fell below $8.0 \mathrm{gm} / \mathrm{dl} .^{12}$ The volume (milliliters) and number of units of all blood products including packed red cells, whole blood, platelets, fresh frozen plasma, and cryoprecipitate administered to each patient in the first 24 hours after CPB were recorded.

Blood samples. Blood samples were taken before administration of heparin, 15 minutes after protamine administration, and 12 hours after cessation of CPB. Blood samples were drawn in precooled tubes containing $1.8 \mathrm{ml}$ of $0.13 \mathrm{~mol} / \mathrm{L}$ trisodium citrate (SRL, Tokyo, Japan). The samples were centrifuged within 30 minutes at $2000 \mathrm{~g}$ at $4^{\circ} \mathrm{C}$. An aliquot of the plasma was snap frozen and stored at $-80^{\circ} \mathrm{C}$ until analysis.

Laboratory assessments. Chromogenic peptide substrates and test specifications from Kabivitrum AB, Stockholm, Sweden, were used for the following functional assays, with reference ranges in parentheses: antithrombin III (S-2238, 80\% to $130 \%)$ and $\alpha_{2}$-plasmin inhibitor (S-2251, 80\% to $130 \%){ }^{13,14}$ Antithrombin III and $\alpha_{2}-$ plasmin inhibitor were measured with a Hitachi model 101 spectrophotometer (Hitachi Medical Corp., Tokyo, Japan). Plasma fibrinogen was measured with the Clauss method. ${ }^{15}$ The international standard $89 / 644$ NIBSC (National Institute for Biological Standards and Control) was used for calibration. Thrombin-antithrombin III complexes were determined by an enzyme immunoassay, and plasminogen activator inhibitor-1 levels were determined by an enzyme-linked immunosorbent assay purchased from Behringwerke AG, Marburg, Germany. ${ }^{16,17}$ D-dimer plasma concentrations were determined by the enzyme-linked immunosorbent assay purchased from Boehringer Mannheim GmbH, Mannheim, Germany. ${ }^{18}$

Renal function. Blood and urine specimens for the measurements of renal function were obtained before the operation and 12 and 36 hours after CPB. The urinary output after CPB was recorded. Creatinine, osmolar, and free water clearances were calculated by standard formulas. Fractional sodium excretion $\left(\% \mathrm{Na}_{\mathrm{Exc}}\right)$ and fractional potassium excretion $\left(\% \mathrm{~K}_{\mathrm{Exc}}\right)$ in percent were calculated as follows:

$$
\begin{gathered}
\% \mathrm{Na}_{\mathrm{Exc}}=\left(\left[\mathrm{Na}_{\mathrm{u}} / \mathrm{Na}_{\mathrm{p}}\right] /\left[\mathrm{Cr}_{\mathrm{u}} / \mathrm{Cr}_{\mathrm{p}}\right]\right) \times 100 \\
\% \mathrm{~K}_{\mathrm{Exc}}=\left(\left[\mathrm{K}_{\mathrm{u}} / \mathrm{K}_{\mathrm{p}}\right] /\left[\mathrm{Cr}_{\mathrm{u}} / \mathrm{Cr}_{\mathrm{p}}\right]\right) \times 100
\end{gathered}
$$

where $\mathrm{Na}_{\mathrm{u}}$ is the concentration of urinary sodium, $\mathrm{Na}_{\mathrm{p}}$ is the concentration of serum sodium, $\mathrm{Cr}_{\mathrm{u}}$ is the concentration of urinary creatinine, $\mathrm{Cr}_{p}$ is the concentration of serum creatinine, $K_{u}$ is the concentration of urinary potassium, and $\mathrm{K}_{\mathrm{p}}$ is the concentration of serum potassium.

Graft patency assessment. Graft angiography was performed on 120 patients (control group, $n=38$; minimaldose group, $n=41$; low-dose group, $n=41$ ) 7 to 47 days after the operation (median 25 days). Forty-seven of 167 patients enrolled in this study were excluded from the postoperative angiographic study because of the following reasons: patient refusal ( $n=28$ : control group, $n=9$; minimal-dose group, $n=11$; low-dose group, $n=8$ ), technical difficulty for either vein or arterial graft access ( $n=12$ : control group, $n=5$; minimal-dose group, $n=3$; low-dose group, $n=4$ ), patient illness ( $n=4$ : control group, $n=3$; low-dose group, $n=1$ ), and patient death ( $n=3$ : control group, $n=2$; low-dose group, $n=1$ ). Selective injection of contrast material in all vein, internal thoracic artery, or right gastroepiploic artery grafts was carried out. A graft and a distal anastomosis were defined as patent if contrast material was seen to flow through the graft into the distal native coronary artery.

Statistical analysis. The sample size calculation was based on estimates of blood loss determined in patients undergoing primary CABG at Kurume university Hospital. The calculations indicated that it would be possible to show a difference greater than or equal to 1.2 standard deviations with a power of $90 \%$ and a significance level of $5 \%$ if 55 patients were evaluated at each treatment group. All results were expressed as mean \pm standard error of the mean for continuous variables. Categoric values were analyzed by means of the $\chi^{2}$ test. The Kruskal-Wallis test was used to evaluate the differences of blood loss and transfusion requirements among the groups. Where the 
Table I. Clinical and operative data

\begin{tabular}{|c|c|c|c|c|}
\hline & Control & Minimal dose & Low dose & $p$ Value \\
\hline No. of patients & 57 & 55 & 55 & \\
\hline Age $(y)$ & $61.2 \pm 1.3$ & $64.4 \pm 1.2$ & $63.2 \pm 1.1$ & 0.17 \\
\hline $\operatorname{Sex}(M / F)$ & $41 / 16$ & $43 / 12$ & $35 / 20$ & 0.24 \\
\hline Body surface area $\left(\mathrm{m}^{2}\right)$ & $1.64 \pm 0.02$ & $1.65 \pm 0.02$ & $1.64 \pm 0.03$ & 0.99 \\
\hline LVEF $(\geq 40 \% /<40 \%)$ & $51 / 6$ & $53 / 2$ & $50 / 5$ & 0.36 \\
\hline NYHA (II-III/IV) & $42 / 15$ & $47 / 8$ & $43 / 12$ & 0.31 \\
\hline $\begin{array}{l}\text { Autologous blood volume do- } \\
\text { nated preoperatively }(\mathrm{ml})\end{array}$ & $159 \pm 55$ & $172 \pm 44$ & $172 \pm 50$ & 0.94 \\
\hline $\begin{array}{l}\text { Preoperative use of platelet- } \\
\text { active drugs* }(\mathrm{Y} / \mathrm{N})\end{array}$ & $29 / 28$ & $25 / 30$ & $24 / 31$ & 0.73 \\
\hline Dose of heparin $\left(\times 10^{4} \mathrm{IU}\right)$ & $2.28 \pm 0.06$ & $2.39 \pm 0.07$ & $2.35 \pm 0.08$ & 0.65 \\
\hline Mean ACT during CPB (sec.) & $545 \pm 22$ & $593 \pm 24$ & $598 \pm 22$ & 0.41 \\
\hline Duration of XCL (min) & $66 \pm 4$ & $74 \pm 3$ & $68 \pm 4$ & 0.24 \\
\hline Duration of CPB (min) & $127 \pm 5$ & $131 \pm 4$ & $129 \pm 5$ & 0.87 \\
\hline No. of distal anastomoses & $2.9 \pm 0.1$ & $3.1 \pm 0.1$ & $2.9 \pm 0.1$ & 0.31 \\
\hline No. of arterial grafts & $1.2 \pm 0.1$ & $1.3 \pm 0.1$ & $1.2 \pm 0.1$ & 0.53 \\
\hline
\end{tabular}

There were no significant differences among the groups for any of the parameters listed. LVEF, Left ventricular ejection fraction; NYHA, New York Heart Association functional class; $A C T$, activated clotting time; $X C L$, aortic crossclamp; $C P B$, cardiopulmonary bypass.

*Aspirin or a nonsteroidal antiinflammatory drug.

Table II. Preoperative and postoperative hemoglobin concentrations (gm/dl)

\begin{tabular}{ccccc}
\hline & $\begin{array}{c}\text { Control } \\
(n=57)\end{array}$ & $\begin{array}{c}\text { Minimal dose } \\
(n=55)\end{array}$ & $\begin{array}{c}\text { Low dose } \\
(n=55)\end{array}$ & $p$ Value \\
\hline Preop. & $13.4 \pm 0.2$ & $12.6 \pm 0.2$ & $13.4 \pm 0.3$ & 0.20 \\
$0 \mathrm{hr}$ & $8.3 \pm 0.1$ & $8.5 \pm 0.2$ & $8.2 \pm 0.1$ & 0.39 \\
$24 \mathrm{hr}$ & $10.9 \pm 0.2$ & $10.9 \pm 0.2$ & $11.4 \pm 0.2$ & 0.10 \\
\hline
\end{tabular}

Preop., Preoperative; $0 \mathrm{hr}$, immediately after cessation of CPB; $24 \mathrm{hr}, 24$ hours after cessation of CPB. Other abbreviations as listed in Table I.

overall test indicated significant between-group differences, pairwise comparisons among the three treatment groups were made. Because of the increased risk of type I error caused by multiple comparisons, a $p$ value less than 0.01 was considered significant for these pairwise comparisons. A two-way repeated-measures analysis of variance was used to test the effect of study groups and sampling time points on parameters of clotting and fibrinolysis and on renal function. When the two-way repeated-measures analysis of variance indicated a significant effect of group or time $(p<0.05)$, the differences were specified with one-way analysis of variance and Duncan's multiple range test. A $p$ value less than 0.05 was considered significant.

\section{Results}

Clinical and operative data of the three patient groups are shown in Table I. No significant differences were noted in age, sex, body surface area, ejection fraction, New York Heart Association functional class, autologous blood volume donated before the operation, preoperative aspirin use, crossclamp time, CPB time, number of distal anastomoses, and number of arterial grafts.
Hemoglobin concentration, blood loss, and transfusion requirements. No statistically significant differences were measured in the hemoglobin concentration among the groups at any time (Table II). Postoperative blood loss and transfusions of packed red cells and all blood products during the first 24 hours after CPB were significantly ( $p=$ 0.001 ) lower in minimal-dose and low-dose groups than in the control group (Table III). The numbers of patients who required transfusion of any donor blood products were $46(80.7 \%)$ in the control group, $31(56.4 \%)$ in the minimal-dose group, and $35(63.6 \%)$ in the low-dose group ( $p=$ 0.02 ). No statistically significant differences in postoperative blood loss and transfusion requirements were seen between patients in the minimaldose and low-dose groups.

Clotting and fibrinolytic systems. The parameters of clotting and fibrinolysis are shown in Figs. 1 and 2. The antithrombin III and fibrinogen levels were significantly $(p<0.05)$ decreased after CPB in all groups; however, no significant differences in 
Table III. Postoperative blood loss and transfusion requirements

\begin{tabular}{|c|c|c|c|c|}
\hline & $\begin{array}{c}\text { Control } \\
(n=57)\end{array}$ & $\begin{array}{c}\text { Minimal dose } \\
\quad(n=55)\end{array}$ & $\begin{array}{l}\text { Low dose } \\
(n=55)\end{array}$ & $p$ Value \\
\hline \multicolumn{5}{|c|}{ Blood loss $(\mathrm{ml})$} \\
\hline $3 \mathrm{hr}$ & $104 \pm 11$ & $72 \pm 8$ & $73 \pm 6$ & 0.082 \\
\hline $6 \mathrm{hr}$ & $236 \pm 31$ & $172 \pm 15$ & $166 \pm 11$ & 0.329 \\
\hline $12 \mathrm{hr}$ & $364 \pm 37$ & $280 \pm 22$ & $247 \pm 13$ & 0.051 \\
\hline $24 \mathrm{hr}$ & $535 \pm 39$ & $415 \pm 27^{*}$ & $368 \pm 17^{*}$ & 0.001 \\
\hline \multicolumn{5}{|c|}{ Transfusion requirements } \\
\hline Packed red cells & $\begin{aligned} 570 & \pm 40 \mathrm{ml} \\
4.3 & \pm 0.3 \mathrm{U}\end{aligned}$ & $\begin{aligned} 379 & \pm 38 \mathrm{ml}^{*} \\
2.9 & \pm 0.3 \mathrm{U}^{*}\end{aligned}$ & $\begin{array}{r}375 \pm 40 \mathrm{ml}^{*} \\
2.8 \pm 0.3 \mathrm{U}^{*}\end{array}$ & 0.001 \\
\hline (Patients) & $(46)$ & (31) & (35) & $(0.02)$ \\
\hline Whole blood & $\begin{array}{l}11 \pm 8 \mathrm{ml} \\
0.1 \pm 0.1 \mathrm{U}\end{array}$ & $\begin{array}{l}0 \mathrm{ml} \\
0 \mathrm{U}\end{array}$ & $\begin{array}{l}0 \mathrm{ml} \\
0 \mathrm{U}\end{array}$ & 0.18 \\
\hline (Patients) & (2) & $(0)$ & $(0)$ & $(0.14)$ \\
\hline Platelets & $0 \mathrm{ml}$ & $0 \mathrm{ml}$ & $0 \mathrm{ml}$ & - \\
\hline & $0 \mathrm{U}$ & $0 \mathrm{U}$ & $0 \mathrm{U}$ & \\
\hline (Patients) & (0) & $(0)$ & $(0)$ & - \\
\hline Fresh frozen plasma & $\begin{array}{c}69 \pm 17 \mathrm{ml} \\
0.9 \pm 0.2 \mathrm{U}\end{array}$ & $\begin{array}{l}51 \pm 15 \mathrm{ml} \\
0.6 \pm 0.2 \mathrm{U}\end{array}$ & $\begin{array}{l}48 \pm 15 \mathrm{ml} \\
0.6 \pm 0.2 \mathrm{U}\end{array}$ & 0.61 \\
\hline (Patients) & (13) & (11) & (9) & $(0.69)$ \\
\hline Cryoprecipitate & $\begin{array}{r}44 \pm 18 \mathrm{ml} \\
0.2 \pm 0.1 \mathrm{U}\end{array}$ & $\begin{aligned} 27 & \pm 12 \mathrm{ml} \\
0.1 & \pm 0.1 \mathrm{U}\end{aligned}$ & $\begin{array}{l}27 \pm 14 \mathrm{ml} \\
0.1 \pm 0.1 \mathrm{U}\end{array}$ & 0.66 \\
\hline (Patients) & (5) & (4) & (5) & $(0.93)$ \\
\hline All blood products & $\begin{array}{r}694 \pm 38 \mathrm{ml} \\
5.7 \pm 0.8 \mathrm{U}\end{array}$ & $\begin{array}{r}457 \pm 36 \mathrm{ml}^{*} \\
3.6 \pm 0.8 \mathrm{U}^{*}\end{array}$ & $\begin{aligned} 450 & \pm 38 \mathrm{ml}^{*} \\
3.5 & \pm 0.8 \mathrm{U}^{*}\end{aligned}$ & 0.001 \\
\hline (Patients) & $(46)$ & (31) & (35) & $(0.02)$ \\
\hline
\end{tabular}

Blood loss and transfusion of packed red cells and all blood products 24 hours after cessation of CPB were significantly lower in the minimal-dose and low-dose groups than in the control group. The $p$ values refer to the results of the Kruskal-Wallis test for transfusion requirements and $\chi^{2}$ test for number of patients. Abbreviations as listed in Table $\mathbf{I}$.

${ }^{*} p<0.01$ versus control.

those parameters were found among the groups at any time point. The thrombin-antithrombin III complexes significantly $(p<0.05)$ increased after CPB and remained significantly high until 12 hours after CPB in all groups; however, no significant differences were found among the groups at any time point. The plasminogen activator inhibitor-1 decreased significantly after CPB in the control group, and the level was significantly $(p<0.05)$ lower than that in the minimal-dose and low-dose groups after CPB. The level of $\alpha_{2}$-plasmin inhibitor was significantly $(p<0.05)$ decreased after CPB in the control group, whereas it increased significantly $(p<0.05)$ after CPB in the minimal-dose and low-dose groups. The $\alpha_{2}$-plasmin inhibitor level after CPB was significantly greater in the minimal- and low-dose groups than in the control group $(p<0.05)$. A marked increase $(p<0.05)$ in D-dimer levels was found in the control group after $\mathrm{CPB}$, and the increase persisted until 12 hours after CPB. In contrast, $D$-dimer levels remained essentially constant in the low-dose group. The D-dimer level was significantly greater in the control group than in the low-dose group immediately after $\mathrm{CPB}$ and 12 hours after CPB.

Renal function parameters. Repeated-measures analysis of variance demonstrated a similar increase in creatinine, osmolar, and free water clearances during the first 12 hours in all groups, with a subsequent fall in levels in all groups 12 and 36 hours after CPB (Table IV). Fractional sodium and potassium excretions also increased after the operation in all groups; however, no statistically significant differences were found among the groups at any time.

Graft patency assessment. A total of 183 vein grafts and 170 arterial grafts were performed in 120 patients. The distribution of vein grafts $(p=0.22)$ and arterial grafts $(p=0.17)$ did not differ significantly among the groups. Also, no significant differences in patency rates of vein grafts and arterial grafts were detected among the three groups either on a per-graft basis or on a per-patient basis (Table V).

Clinical outcomes. No significant allergic reaction to aprotinin was observed in 110 patients who 


\section{Control}

\section{$-0-$ Minimal}
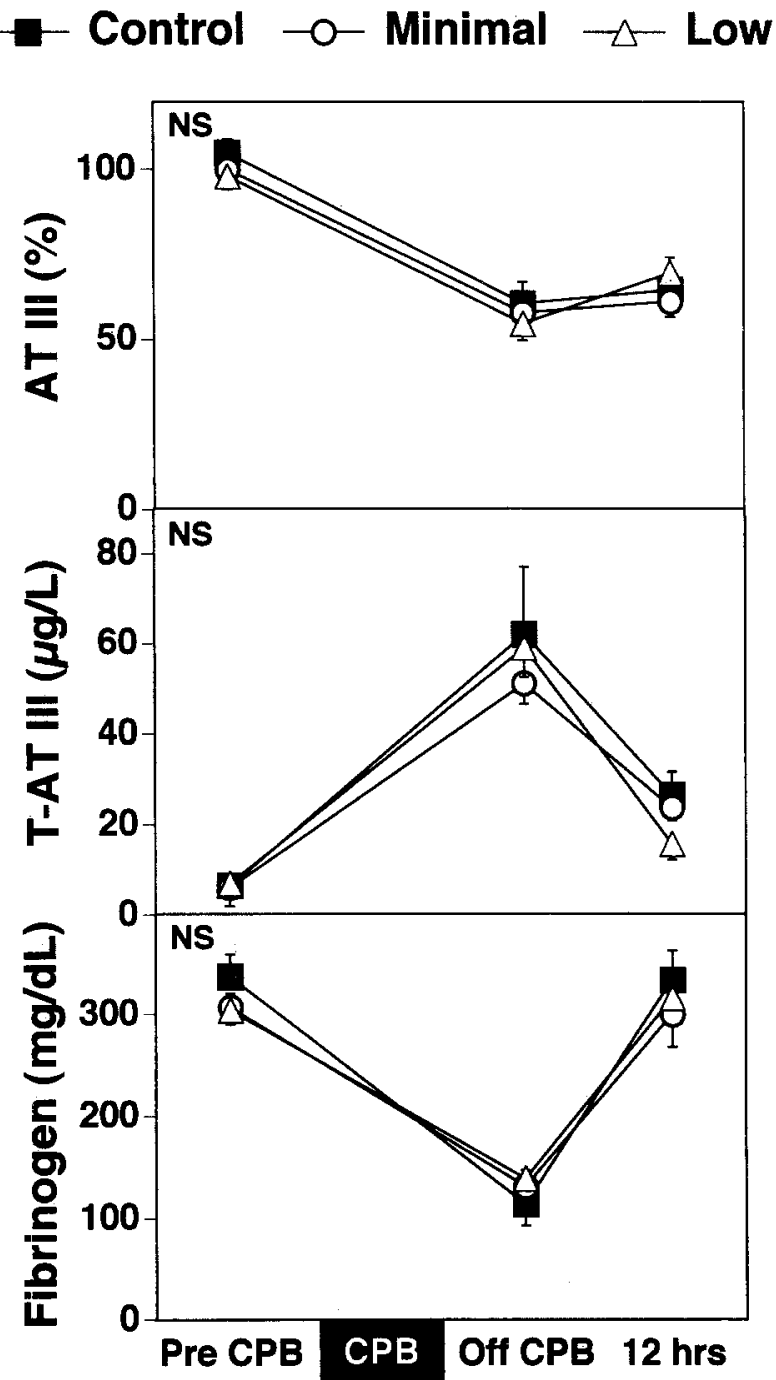

Fig. 1. The antithrombin III (AT III) and the fibrinogen levels were significantly $(p<0.05)$ decreased and the thrombin-antithrombin III complexes ( $T-A T I I I)$ significantly $(p<0.05)$ increased after CPB in all groups; however, no significant differences in those parameters were found among the groups at any time point. Control, Control group; Minimal, minimal-dose group; Low, lowdose group; $C P B$, cardiopulmonary bypass; Pre $C P B$, before administration of heparin; $O$ ff $C P B, 15$ minutes after protamine administration; $12 \mathrm{hrs}, 12$ hours after cessation of CPB.

received aprotinin. Three patients died, two in the control group and one in the low-dose group. One patient in the control group died of severe pulmonary dysfunction from an unknown cause after the operation. The other patient in the control group, who underwent $\mathrm{CABG}$ while in a state of cardio-

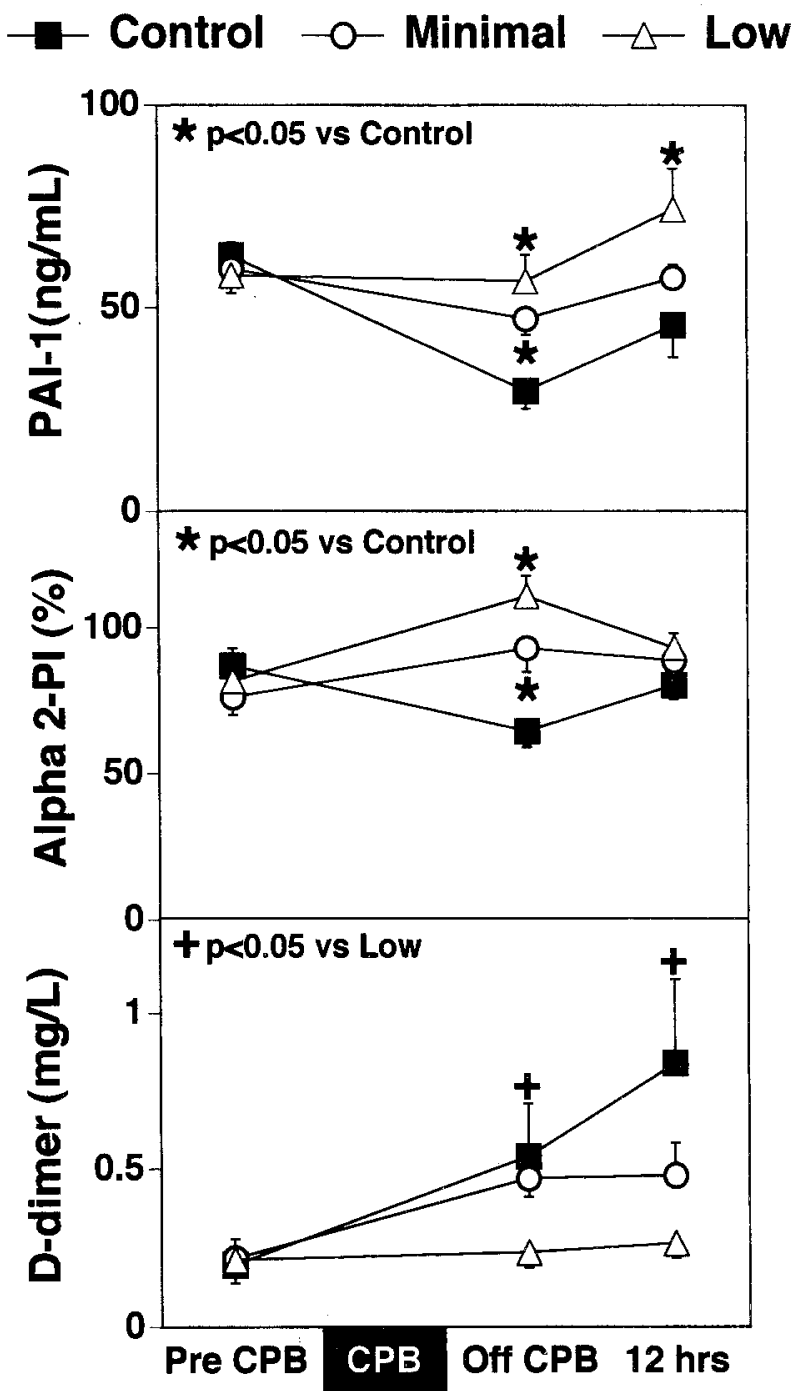

Fig. 2. The plasminogen activator inhibitor-1 (PAI-1) and the $\alpha_{2}$-plasmin inhibitor (Alpha 2-PI) levels were significantly greater in the minimal- and low-dose groups than in the control group after CPB. The D-dimer was significantly greater in the control group than in the low-dose group after CPB and 12 hours after CPB. Abbreviations as listed in Fig. 1.

genic shock resulting from an acute myocardial infarction, died of multiple organ failure on postoperative day 12 . One patient in the low-dose group became profoundly hypotensive immediately after the administration of protamine and subsequently died of multiple organ failure on postoperative day 19. Nine patients had a perioperative myocardial infarction (defined as the appearance of new $Q$ waves with a concomitant rise in the MB fraction of creatine kinase)-five patients in the control group, 
Table IV. Preoperative and postoperative renal functions

\begin{tabular}{|c|c|c|c|c|}
\hline & $\begin{array}{l}\text { Control } \\
(n=57)\end{array}$ & $\begin{array}{l}\text { Minimal dose } \\
\quad(n=55)\end{array}$ & $\begin{array}{l}\text { Low dose } \\
(n=55)\end{array}$ & $p$ Value \\
\hline \multicolumn{5}{|c|}{ Creatinine clearance $(\mathrm{ml} / \mathrm{min})$} \\
\hline Preop. & $60.7 \pm 3.0$ & $51.9 \pm 3.5$ & $60.6 \pm 4.4$ & 0.16 \\
\hline $0-12$ hours & $107.5 \pm 11.1^{*}$ & $108.6 \pm 10.0^{*}$ & $84.1 \pm 8.9^{*}$ & 0.19 \\
\hline 12-36 hours & $75.3 \pm 3.9$ & $87.5 \pm 7.4$ & $83.9 \pm 10.3$ & 0.46 \\
\hline \multicolumn{5}{|c|}{ Osmolar clearance $(\mathrm{ml} / \mathrm{min})$} \\
\hline Preop. & $1.38 \pm 0.07$ & $1.39 \pm 0.14$ & $1.31 \pm 0.10$ & 0.84 \\
\hline $0-12$ hours & $4.22 \pm 0.22^{*}$ & $4.68 \pm 0.27^{*}$ & $4.09 \pm 0.18^{*}$ & 0.18 \\
\hline 12-36 hours & $2.12 \pm 0.10$ & $2.27 \pm 0.13$ & $1.92 \pm 0.09$ & 0.10 \\
\hline \multicolumn{5}{|c|}{ Free water clearance $(\mathrm{ml} / \mathrm{min})$} \\
\hline Preop. & $-0.52 \pm 0.07$ & $-0.47 \pm 0.11$ & $-0.33 \pm 0.11$ & 0.35 \\
\hline $0-12$ & $-1.46 \pm 0.12^{*}$ & $-1.45 \pm 0.17^{*}$ & $-1.01 \pm 0.19^{*}$ & 0.11 \\
\hline 12-36 hours & $-0.74 \pm 0.09$ & $-0.71 \pm 0.11$ & $-0.71 \pm 0.08$ & 0.96 \\
\hline \multicolumn{5}{|c|}{ Fractional sodium excretion (\%) } \\
\hline Preop. & $0.86 \pm 0.06$ & $1.08 \pm 0.13$ & $0.95 \pm 0.09$ & 0.23 \\
\hline $0-12$ hours & $1.63 \pm 0.22 *$ & $2.71 \pm 0.40^{*}$ & $2.52 \pm 0.45^{*}$ & 0.08 \\
\hline 12-36 hours & $1.14 \pm 0.12$ & $1.37 \pm 0.33$ & $1.20 \pm 0.47$ & 0.87 \\
\hline \multicolumn{5}{|c|}{ Fractional potassium excretion (\%) } \\
\hline Preop. & $9.1 \pm 0.05$ & $10.5 \pm 1.0$ & $8.9 \pm 0.6$ & 0.24 \\
\hline $0-12$ hours & $26.7 \pm 1.3^{*}$ & $32.3 \pm 2.4^{*}$ & $31.5 \pm 2.6^{*}$ & 0.13 \\
\hline 12-36 hours & $21.8 \pm 1.6^{*}$ & $20.0 \pm 2.6^{*}$ & $25.3 \pm 7.3^{*}$ & 0.68 \\
\hline
\end{tabular}

The $p$ values refer to the results of one-way analysis of variance. Abbreviations as listed in Tables I and II.

${ }^{*} p<0.05$ versus preoperative value.

Table V. Patency of saphenous vein grafts and arterial grafts

\begin{tabular}{|c|c|c|c|c|}
\hline & Control $(n=38)$ & Minimal dose $(n=41)$ & Low dose $(n=41)$ & $p$ Value \\
\hline \multicolumn{5}{|c|}{ Patency of saphenous vein grafts } \\
\hline $\begin{array}{l}\text { Patent grafts/total grafts } \\
\text { (per-graft basis) }\end{array}$ & $\begin{array}{c}61 / 65 \\
(93.8 \%)\end{array}$ & $\begin{array}{c}65 / 66 \\
(98.5 \%)\end{array}$ & $\begin{array}{c}60 / 65 \\
(92.3 \%)\end{array}$ & 0.25 \\
\hline $\begin{array}{l}\text { No. of patients with all grafts patent } \\
\text { (per-patient basis) }\end{array}$ & $\begin{array}{c}34 / 38 \\
(89.5 \%)\end{array}$ & $\begin{array}{c}40 / 41 \\
(97.6 \%)\end{array}$ & $\begin{array}{c}36 / 41 \\
(87.8 \%)\end{array}$ & 0.24 \\
\hline \multicolumn{5}{|c|}{ Patency of arterial grafts } \\
\hline $\begin{array}{l}\text { Patent grafts/total grafts } \\
\text { (per-graft basis) }\end{array}$ & $\begin{array}{l}50 / 50 \\
(100 \%)\end{array}$ & $\begin{array}{c}62 / 64 \\
(96.9 \%)\end{array}$ & $\begin{array}{c}55 / 56 \\
(98.2 \%)\end{array}$ & 0.46 \\
\hline $\begin{array}{l}\text { No. of patients with all grafts patent } \\
\text { (per-patient basis) }\end{array}$ & $\begin{array}{c}38 / 38 \\
(100 \%)\end{array}$ & $\begin{array}{c}39 / 41 \\
(95.1 \%)\end{array}$ & $\begin{array}{c}40 / 41 \\
(97.6 \%)\end{array}$ & 0.39 \\
\hline
\end{tabular}

one in the minimal-dose group, and three in the low-dose group. Nine patients had low-output syndrome after the operation (defined as a requirement for inotropic medication or balloon pump support, or both, because of a cardiac index of less than $2.1 \mathrm{~L}$ $\cdot \min ^{-1} \cdot \mathrm{m}^{-2}$ and a systolic blood pressure less than $90 \mathrm{~mm} \mathrm{Hg}$, despite an adequate preload and correction of any electrolyte disorders)-five patients in the control group, one in the minimal-dose group, and three in the low-dose group. No significant differences were apparent in these results among the groups.

\section{Discussion}

Many studies have examined the hemostatic efficacy of aprotinin and have demonstrated significant reductions in postoperative blood loss and transfusion requirements in patients undergoing cardiac operations. ${ }^{1-10}$ The efficacy of aprotinin as a hemostatic agent is unquestionable, but concerns about the side effects of aprotinin have been raised. A higher prevalence of postoperative renal dysfunction and early vein graft occlusion has been reported in patients receiving high-dose aprotinin. ${ }^{9-11}$ In previous reports, high-dose aprotinin has been shown to 
cause a transient decrease in tubular sodium reabsorption. ${ }^{19,20}$ It has been suggested that these side effects of aprotinin may be dose dependent. ${ }^{21}$ In recent studies comparing low-dose aprotinin with placebo, low-dose aprotinin has been shown to prevent enhanced fibrinolysis and reduce postoperative blood loss. ${ }^{7,8}$ Furthermore, low-dose aprotinin was reported to be as effective as high-dose aprotinin in preserving glycoprotein $\mathrm{Ib}$ receptors and reducing blood loss. ${ }^{5}$ It seems reasonable, therefore, that the dose might be minimized to reduce the prevalence of side effects and the costs. However, minimal-dose aprotinin with hemostatic efficacy comparable with that of high-dose aprotinin and without any side effects has not yet been recommended.

Hemostatic efficacy. Covino and colleagues ${ }^{22}$ reported that low-dose aprotinin $\left(1 \times 10^{6} \mathrm{KIU}\right.$ in the priming solution and $0.5 \times 10^{6} \mathrm{KIU} / \mathrm{hr}$ during the operation) was effective in reducing blood loss and transfusion requirements, but quarter-dose aproti$\operatorname{nin}\left(0.5 \times 10^{6} \mathrm{KIU}\right.$ in the pump prime and $0.25 \times$ $10^{6} \mathrm{KIU} / \mathrm{hr}$ during the operation) was not. Van Oeveren and colleagues ${ }^{5}$ reported that low-dose aprotinin $\left(2 \times 10^{6} \mathrm{KIU}\right.$ aprotinin only in the pump prime) preserved glycoprotein $\mathrm{Ib}$ receptor and reduced blood loss and transfusion requirements similarly to high-dose aprotinin (bolus infusion of $2 \times$ $10^{6} \mathrm{KIU}$ aprotinin during induction of anesthesia followed by a continuous infusion of $0.5 \times 10^{6}$ $\mathrm{KIU} / \mathrm{hr}$ and additional bolus of $2 \times 10^{6} \mathrm{KIU}$ aprotinin in the pump prime). They concluded that the protection of the platelet adhesive capacity through the platelet glycoprotein $\mathrm{Ib}$ receptor was obtained when aprotinin was present in sufficient amounts $\left(2 \times 10^{6} \mathrm{KIU}\right.$ in the pump prime) at the first pass of blood through a circuit containing a membrane oxygenator. In the present study, the minimal-dose aprotinin regimen reduced the postoperative blood loss and transfusion requirements similarly to the low-dose regimen. Therefore, the dose of $1 \times 10^{6}$ KIU added only in the pump prime may be the acceptable minimum dose for the reduction of postoperative blood loss, whereas the dose of $0.5 \times 10^{6}$ KIU may be insufficient to be effective.

In previous reports, high-dose aprotinin has been shown to inhibit enhanced fibrinolytic activity during CPB and reduce postoperative blood loss. ${ }^{3,19} \mathrm{Re}-$ cently, low-dose aprotinin was also reported to have an inhibitory effect on enhanced fibrinolytic activity by increasing $\alpha_{2}$-antiplasmin and by decreasing fibrin(ogen) degradation products. ${ }^{7,8}$ In the present study, we also found that low-dose aprotinin increased $\alpha_{2}$-plasmin inhibitor, plasminogen activator inhibitor-1, and decreased D-dimer levels during CPB compared with levels found in the control group. Although minimal-dose aprotinin did not decrease D-dimer levels after CPB as the low-dose aprotinin did, it significantly increased the levels of the $\alpha_{2}$-plasmin inhibitor and the plasminogen activator inhibitor- 1 compared with those of the control group. These results suggest that minimal-dose aprotinin also has an inhibitory effect on enhanced fibrinolytic activity after CPB, which is sufficient for the preservation of hemostatic efficacy. Our study also demonstrated that the marked reduction of antithrombin III and fibrinogen and the increase of the thrombin-antithrombin III complexes after CPB in both aprotinin groups were comparable with those in the control group. The results were similar to previous reports that describe the hemostatic mechanism of aprotinin., 3,8 The similar changes between the control group and the aprotinin groups in regard to those clotting parameters suggest few additional inhibitory effects on the activation of the clotting system by the doses used in this study. However, aprotinin has been reported to prolong the activated clotting time synergetically through the intrinsic clotting pathway by inhibiting kallikrein in a dose-related manner., ${ }^{63}$ Therefore high-dose aprotinin may have an inhibitory effect on the activation of the intrinsic clotting system, whereas lower doses may not. Thus there is a risk of underheparinization if the activated clotting time is used as a monitor of adequacy of heparinization when aprotinin is present. As suggested in a previous study, ${ }^{24}$ the activated clotting time of greater than 400 seconds used in this study may have been inadequate in patients receiving aprotinin.

Renal function. Blauhut and colleagues ${ }^{19}$ reported the increase of fractional sodium excretion during late intraoperative and early postoperative stages, which might reflect incipient renal tubular failure. However, they also found that renal function was unremarkable 24 hours after the operation. In the present study, fractional sodium excretion was slightly $(p=0.08)$ greater in aprotinin-treated patients during the first 12 hours after CPB. The result, as other investigators suggested, ${ }^{19,20}$ might reflect a transient reduction of sodium reabsorption caused by renal tubular insufficiency. However, fractional sodium excretions in all groups became virtually identical $(p=0.87)$ by 36 hours after CPB. Furthermore, creatinine, osmolar, and free water clearances 
were above normal during the early postoperative period in all groups, and no significant differences were detected among the groups. The results suggested that aprotinin use was not associated with a significant increase in the prevalence of renal dysfunction. Sundt and colleagues ${ }^{10}$ reported that aprotinin was associated with an increased risk of renal dysfunction in patients undergoing procedures on the thoracic or thoracoabdominal aorta in which hypothermic circulatory arrest was used. Other investigators suggested that adverse effects on renal function could be temperature dependent. ${ }^{21} \mathrm{Be}$ cause the systemic temperature in our patients was not cooled below $30^{\circ} \mathrm{C}$ (mean systemic temperature, $33^{\circ} \pm 1^{\circ} \mathrm{C}$ ), the effect of aprotinin use on renal function was not investigated under hypothermic conditions. Therefore further investigations regarding the effect of aprotinin on renal function should be performed in patients undergoing hypothermic $\mathrm{CPB}$ and in patients with preexisting renal impairment,

Graft patency. Cosgrove and colleagues ${ }^{9}$ have shown a trend toward an increased incidence of myocardial infarction in aprotinin-treated patients. Postmortem findings in their study demonstrated acute vein occlusions and widespread thrombosis in the kidney, native coronary $\mathrm{ssels,} \mathrm{and} \mathrm{cerebral}$ vessels in isolated patients. The early formation of thrombi on pulmonary artery catheters in patients receiving high-dose aprotinin has also been reported. $^{25,26}$ Because of these reports, concerns of early vein graft occlusion in patients undergoing CABG have been raised ${ }^{11}$ In contrast, several investigators have demonstrated that aprotinin did not influence early vein graft patency. ${ }^{27-29}$ A multicenter study also has demonstrated that aprotinin was not associated with an increased risk of myocardial infarction in patients undergoing repeated $\mathrm{CABG}{ }^{30}$ Using coronary arteriography in 120 patients, we also demonstrated that neither minimal-dose nor low-dose aprotinin contributed to the early vein graft occlusion and the prevalence of perioperative myocardial infarction. The results of our study and previous studies ${ }^{27-30}$ suggest that aprotinin has no adverse effect on early vein graft patency. However, inasmuch as 47 of 167 patients (28\%) were excluded from the postoperative angiographic study, patient selection might have been biased. Moreover, because the number of patients involved in the study was relatively small to detect a difference in lowincidence events such as graft occlusion or renal dysfunction, the potential for a type II statistical error exists. Therefore further investigations involving more patients are required to assert the conclusions regarding the incidence of complications in association with aprotinin.

So that the adverse side effects of systemic aprotinin can be avoided, effects of topical application of low-dose aprotinin into the pericardial cavity have been investigated. ${ }^{31-33}$ The technique has been reported to reduce postoperative blood loss and transfusion requirements without significant side effects. ${ }^{31-33}$ The technique therefore may provide a potential to amplify the hemostatic efficacy and consequently minimize the systemic use of the regimen. However, because the mechanism of topical aprotinin action is still unclear, further investigations are required for its routine use.

In summary, neither minimal-dose nor low-dose aprotinin was associated with a significant increase in the prevalence of renal dysfunction and early vein graft occlusion. Inhibition of fibrinolysis and significant reductions of blood loss and transfusion requirements were demonstrated in patients receiving minimal-dose aprotinin, as well as in patients receiving low-dose aprotinin. The results suggested that the dose of $1 \times 10^{6} \mathrm{KIU}$ added to the pump prime was acceptably effective in reducing blood loss for primary CABG without significant side effects. Minimal-dose aprotinin may provide the optimal risk/ benefit balance.

\section{REFERENCES}

1. Royston D, Bidstrup BP, Taylor KM, Sapsford RN. Effect of aprotinin on need for blood transfusion after repeat openheart surgery. Lancet 1987;2:1289-91.

2. van Oeveren W, Jansen NJG, Bidstrup BP, Royston D, Westaby S, Neuhof H, et al. Effects of aprotinin on hemostatic mechanisms during cardiopulmonary bypass. Ann Thorac Surg 1987:44:640-5.

3. Havel M, Teufelsbauer H, Knöbl P, Dalmantiner R, Jaksch $\mathrm{P}$, Zwölfer $\mathrm{W}$, et al. Effect of intraoperative aprotinin administration on postoperative bleeding in patients undergoing cardiopulmonary bypass operation. J Thorac Cardiovasc Surg 1991;101:968-72.

4. Rocha E, Hidalgo F, Llorens R, Melero JM, Arroyo JL, Paramo JA. Randomized study of aprotinin and DDAVP to reduce postoperative bleeding after cardiopulmonary bypass surgery. Circulation 1994;90:921-7.

5. van Oeveren W, Harder MP, Roozendaal KJ, Eijsman L, Wildevuur CRH. Aprotinin protects against the initial effect of cardiopulmonary bypass. J Thorac Cardiovasc Surg 1990; 99:788-97.

6. de Smet AAEA, Joen MCN, van Oeveren W, Roozendaal KJ, Harder MP, Eijsman L, et al. Increased anticoagulation during cardiopulmonary bypass by aprotinin. J Thorac Cardiovasc Surg 1990;100:520-7.

7. Kawasuji M, Ueyama K, Sakakibara N, Tedoriya T, Matsu- 
naga $Y$, Misaki $T$, et al. Effect of low-dose aprotinin on coagulation and fibrinolysis in cardiopulmonary bypass. Ann Thorac Surg 1993;55:1205-9.

8. Liu B, Tengborn L, Larson G, Radberg LOG, Belboul A, Dernevik L, et al. Half-dose aprotinin preserves hemostatic function in patients undergoing bypass operations. Ann Thorac Surg 1995;59:1534-40.

9. Cosgrove DM, Heric B, Lytle BW, Taylor PC, Novoa R, Golding LAR, et al: Aprotinin therapy for reoperative myocardial revascularization: a placebo-controlled study. Ann Thorac Surg 1992;54:1031-8.

10. Sundt TM, Kouchoukos NT, Saffitz JE, Murphy SF, Wareing $\mathrm{TH}$, Stahl DJ. Renal dysfunction and intravascular coagulation with aprotinin and hypothermic circulatory arrest. Ann Thorac Surg 1993;55:1418-24.

11. Westaby S. Aprotinin in perspective. Ann Thorac Surg 1993;55:1033-41.

12. Lemmer JH. Reporting the results of blood conservation studies: the need for uniform and comprehensive methods. Ann Thorac Surg 1994;58:1305-6.

13. Scully MF, Kakkar VV. Methods for semi micro or automated determination of thrombin, antithrombin, and heparin cofactor using the substrate, H-d-Phe-Pip-Arg-p-nitroanilide - 2 HCl. Clin Chim Acta 1977;79:595-602.

14. Friberger P, Knös M, Gustavsson S, Aurell L, Claeson G. Methods for determination of plasmin, antiplasmin and plasminogen by means of substrate S-2251. Haemostasis 1978;7:138-45.

15. Clauss VA. Rapid physiological coagulation method for the determination of fibrinogen. Acta Haematol 1957;17:237-46.

16. Toyokawa M, Suehisa E, Nishimura K, Suetomo M, Kouda $\mathrm{K}$, Amino N, et al. Fundamental study and clinical efficacy of thrombin-antithrombin III complex [in Japanese]. Igaku Yakugaku 1990;23:959-66.

17. Declerck P, Alessi MC, Verstreken M, Kruithof EKO, Juhan-Vague I, Collen D. Measurement of plasminogen activator inhibitor 1 in biologic fluids with a murine monoclonal antibody based enzyme-linked immunosorbent assay. Blood 1988;71:220-5.

18. Elms MJ, Bunce IH, Bundessen PG, Rylatt DB, Webber AJ, Masci PP, et al. Measurement of crosslinked fibrin degradation products: an immunoassay using monoclonal antibodies. Thromb Haemostas 1983;50:591-4.

19. Blauhut B, Gross C, Necek S, Doran JE, Späth P, Lundsgaard-Hansen P. Effects of high-dose aprotinin on blood loss, platelet function, fibrinolysis, complement, and renal function after cardiopulmonary bypass. J Thorac Cardiovasc Surg 1991;101:958-67.

20. Fischer JH, Knupfer P. High dose aprotinin (Trasylol) therapy: harmless to the kidney. Langenbecks Arch Chir 1983; $360: 241-9$.
21. Fischer JH. Effects of Trasylol on the kidneys: dependence on temperature and dose. In: Dudziak R, Reuter HD, Kirchoff PG, Schumann F, editors. Proteolysis and proteinase inhibitor in cardiac and vascular surgery. Stuttgart: Schattauer Verlag; 1985. pp. 127-35.

22. Covino E, Pepino P, Iorio D, Marino L, Ferrara P, Spampinato $\mathrm{N}$. Low dose aprotinin as blood saver in open heart surgery. Eur J Cardiothorac Surg 1991;5:414-8.

23. Najman DM, Walenga JM, Fareed J, Pifarré R. Effects of aprotinin on anticoagulant monitoring: implications in cardiovascular surgery. Ann Thorac Surg 1993;55:662-6.

24. Hunt BJ, Segal HC, Yacoub M. Guidelines for monitoring heparin by the activated clotting time when aprotinin is used during cardiopulmonary bypass [letter]. $\mathrm{J}$ Thorac Cardiovasc Surg 1992;1134:211-2.

25. Bohrer $\mathbf{H}$, Fleischer $\mathbf{F}$, Lang $\mathbf{J}$, Vahr C. Early formation of thrombi on pulmonary artery catheters in cardiac surgical patients receiving high-dose aprotinin. J Cardiothorac Anesth 1990;4:222-5.

26. Youngberg JA. Aprotinin and thrombus formation on pulmonary artery catheters: a piece of the coagulation puzzle. J Cardiothorac Anesth 1990;4:155-8.

27. Bidstrup BP, Underwood SR, Sapsford RN. Effect of aprotinin (Trasylol) on aorta-coronary bypass graft patency. J Thorac Cardiovasc Surg 1993;105:147-53.

28. Lemmer JH, Stanford W, Bonney SL, Breen JF, Chomka EV, Eldredge WJ, et al. Aprotinin for coronary bypass operations: efficacy, safety, and influence on early saphenous vein graft patency-a multicenter, randomized, double-blind, placebo-controlled study. J Thorac Cardiovase Surg 1994; 107:543-53.

29. Havel M, Grabenwög F, Schneider J, Laufer G, Wollenek G, Owen A, et al. Aprotinin does not decrease early graft patency after coronary bypass grafting despite reducing postoperative bleeding and use of donated blood. J Thorac Cardiovasc Surg 1994;107:807-10.

30. Levy JH, Pifarré R, Schaff HV, Horrow JC, Albus R, Spiess $\mathrm{B}$, et al. A multicenter, double-blind, placebo-controlled trial of aprotinin for reducing blood loss and the requirement for donor-blood transfusion in patients undergoing repeat coronary artery bypass grafting. Circulation 1995;92:2236-44.

31. Tatar H, Cicek S, Demirkilic U, Özal E, Süer H, Öztürk Ö, et al. Topical use of aprotinin in open heart operations. Ann Thorac Surg 1993;55:659-61.

32. O'Regan DJ, Giannopoulos N, Mediratta N, Kendall SWH, Forni A, Pillai R, et al. Topical aprotinin in cardiac operations. Ann Thorac Surg 1994;58:778-81.

33. Tabuchi N, de Haan J, van Oeveren W. Topical effect of aprotinin on the surgical wound in cardiac surgery. $\mathrm{J}$ Thorac Cardiovasc Surg 1995;109:399-400. 